\title{
PHYTOCHEMICAL ANALYSIS OF Curcuma caccia IN DIFFERENT SOLVENTS CHETNA RAHANGDALE ${ }^{a}$ AND BHAWANA PANDEY ${ }^{\text {b1 }}$
}

\author{
${ }^{a}$ School of Biological and Chemical Science, MATS University, Raipur, Chhattisgarh, India \\ ${ }^{\mathrm{b}}$ Department of Biotechnology \& Microbiology, Bhilai Mahila Mahavidayalaya, Bhilai, Durg, Chhattisgarh, India
}

\begin{abstract}
Curcuma caccia is normally known as kali haldi and it has a place with the family Zingiberaceae. This herb is accessible all through north-east focal India, papi slopes of east Godavri, west Godavari and Andhra Pradesh. In the conventional arrangement of prescriptions, new and dried Rhizome and leave concentrate of Curcuma caecia are utilized in treating leucoderma, asthma, tumor, heaps, bronchitis, wounds and so forth. Hot and cold extractions were performed by utilizing distinctive dissolvable. In phytochemical examination researched that alkaloid terpenoids, phenols and tannins, sponins, flovonoids, protein, steroids, cardiacglycosides are mostly present in methanolic concentrate and DPPH searching action were perform to identify cell reinforcement capability of Curcuma caccia plant remove arranged from various dissolvable framework. This article exposes the real dynamic compound present in Curcuma caccia that might be essential from the pharmacological reason.
\end{abstract}

KEYWORDS: Curcuma caccia, Phytochemical Analysis, DPPH etc.

Curcuma caccia Linn. could be a mammoth class bliss to the family Zingiberaceae. It incorporates with respect to seventy types of stem herbs conveyed essentially in land region as wild and developed plants. Curcuma caccia could be a perpetual herb with somewhat blue dark rhizome native to Northeast and Central Bharat Family Curcuma caccia (Black Turmeric) is furthermore inadequately begun in Papi Hills of East Godavari, West Godavari, and Khammam Districts of state. The rhizomes of family Curcuma caccia have a high monetary significance inferable from its indicated medicative properties. The rhizomes territory unit utilized in the treatment of smooth relaxant movement (Arulmozhi et. al., 2006) hemorrhoids, uncleanliness, asthma, malignancy, epilepsy, fever, wound, spewing, emanation issue, anthelmentic, love potion, aggravation, gonorrhoeal releases, and so forth (Sasikumar, 2005) (Rajamma et. al., 2012).

The rhizomes of the plant region unit fragrant in nature. The inward a piece of the stem is pale blue dark in shading and emanates a trademark sweet smell, on account of essence of oil (Pandey and Chowdhary, 2003) generally, the rhizomes of variety Curcuma caccia Roxb. region unit utilized in treating leucoderma, tumors , asthma, heaps, respiratory confusion and so on. The glue is connected on wounds, injuries and rheumatic torments. (Sarangthem and Haokip, 2010) (Sonjit et. al., 2013) late stem bubbling is utilized as anti diarrhoeiaric and to prompt help from midriff hurt. The ongoing stem glue of family Curcuma caesia is Roxb connected all through the snake nibble and scorpion chomp (Kagyung et. al., 2010) (Tag et. al., 2007), Pharmacognostic parameters for assessment of the rhizomes of Curcuma caccia assessed (Paliwal et. al., 2011).

Assessment of Phytochemical constituents in Conventional and Non-traditional types of Curcuma caesia (Paliwal, 2012) Phytochemical Analysis of Methanolic concentrate of Curcuma longa Linn. (Saxena Jyoti and Sahu, 2012).

\section{MATERIALS AND METHODS}

\section{Plant Material Collection and Extraction}

\section{Sample Collection}

The rhizomes of Curcuma caecia were collected from field of Durg and Bhilai, so the plant known taxonomically and was preserved for extraction.

\section{Readiness of Solvent Extracts for Monocot Family Curcuma caecia Rhizomes}

The rhizomes of monocot sort Curcuma caccia were legitimately washed with running water, at that point once evacuation rhizomes were shed dried and pulverized to ask powder. Dried powder of monocot variety Curcuma caccia rhizomes in regards to $50 \mathrm{gm}$ were hot separated with 5 hundred cc fuel abuse soxhelt instrumentation. The soxheletion at $30^{\circ} \mathrm{c}$ was improved the situation multi week to get separate. The concentrate was vanished in water shower at $70^{\circ} \mathrm{c}$ to get rough for phytochemical 
investigation. When the all out vanishing, the heap of the concentrates was recorded and after that marked. The extractions put away independently at $4^{\circ} \mathrm{C}$ in impermeable.

\section{Maceration Technique for Curcuma caecia Leaves}

After Dried powder of Curcuma caesia rhizomes about $50 \mathrm{gm}$ were of cold extracted with $200 \mathrm{ml}$ Petrolium Ether using rotary shaker and were incubated for 1 week at $25^{\circ} \mathrm{c}$ at least 5 times vibration per day. The extract were filtered exploitation textile material and gaseous exploitation rotary distillation instrumentation, this extract dried in $50^{\circ} \mathrm{C}$ oven for 24 hours and finally kept at $4^{\circ} \mathrm{C}$ temperature applied the phytochemical Test, the upper than phytoconstituents were found in monocot Curcuma caecia rhizomes extract.

\section{IDENTIFICATION TESTS PHYTOCHEMICAL CONSTITUENTS}

FOR

The tests were performed to seek out the presence of active chemical constituents like carbohydrates, proteins, starch, amino acids, steroids glycosides, flavonoids, alkaloids, tannins, saponins, phenols by the subsequent procedure. Phytochemical analysis was applied for all the extracts mistreatment normal ways.

\section{Test for Carbohydrate}

Molisch's test: $3 \mathrm{ml}$ of Molisch's reagent was added to the $3 \mathrm{ml}$ of test solution, shaken for few minutes. Then $2 \mathrm{ml}$ of concentrated sulphuric acid was added slowly from the sides of the test tube. The development of a purple ring at the junction of two liquids indicates the presence of carbohydrates.

\section{Test for Proteins}

Biuret test: $3 \mathrm{ml}$ of the test solution was treated with 4\% sodium hydroxide (3- 5 drops) and 1\% copper sulphate solution (3-5 drops). The appearance of blue colour indicates the presence of proteins.

\section{Test for Quinones}

About $0.5 \mathrm{~g}$ of plant extract was taken and additional one cc of extract and one cc of concentrate $\mathrm{H}_{2} \mathrm{SO}_{4}$ was additional formation of red color shows the presence of quinones. One drop of ethanolic Test resolution is placed on a filter-paper, followed by one drop of ethanolic phenylacetonitrile resolution and one drop of
$0.1 \mathrm{~N}$ hydroxide. A positive response is indicated by the looks of a blue or violet stain edged by a yellow ring.

\section{Test for Aminoacids}

Ninhydrin test: Test solution $(3 \mathrm{ml})$ and 3 drops of $5 \%$ lead acetate solution were boiled on water bath for 10 min. Change in the colour of solution to purple or blue indicates the presence of amino acids.

\section{Test for Steroids}

Salkowski test: Chloroform $(2 \mathrm{ml})$ and $2 \mathrm{ml}$ of concentrated sulphuric acid were added to $2 \mathrm{ml}$ of test solution, shaken and allowed to stand. Change in the colour of lower chloroform layer to red and acid layer to greenish yellow fluorescence indicates the presence of steroids.

\section{Test for Glycosides}

Keller-Kiliani test: Glacial acetic acid (3-5 drops), one drop of $5 \% \mathrm{FeCl}_{3}$ and conc. Sulphuric acid were added to the test tube containing $2 \mathrm{ml}$ of T.S. Appearance of reddish-brown color at the junction of two layers and bluish green in the upper layer indicates the presence of glycosides.

\section{Test for Flavanoid}

Shinoda test: To the powdered extract $(10 \mathrm{mg}), 5$ $\mathrm{ml}$ of ethanol (95\%), 3 drops of hydrochloric acid and 0.5 gm magnesium turnings were added. Change of colour of solution to pink indicates the presence of flavonoids.

\section{Test for Alkaloids}

To the dry extract $(20 \mathrm{mg})$ dilute hydrochloric acid (1-2 ml) was added, shaken well and filtered. With filtrate the following tests were performed.

(A) Mayer's test: To the $3 \mathrm{ml}$ of test solution 3 drops of Mayer's reagent (potassium mercuric iodide) was added. Appearance of reddish brown or cream precipitate indicates the presence of alkaloids.

(B) Dragendorff's test: $3 \mathrm{ml}$ of the test solution was mixed with Dragendorff's reagent (potassium bismuth iodide). Appearance of reddish brown precipitate indicates the presence of alkaloids.

\section{Test for Terpenoids}

Salkowski test: Concentrated sulphuric acid (2 $\mathrm{ml}$ ) was added to $2 \mathrm{ml}$ of test solution. The solution was 
shaken and allowed to stand. The colour of lower layer changes to yellow indicating the presence of triterpenoids.

\section{Test for Saponins}

Foam Test: Powdered extract (10-20 mg) was shaken vigorously with water $(1 \mathrm{ml})$. Development of persistent foam which is stable at least for 15 minutes indicates the presence of saponin.

\section{Test for Phenols}

Ferric Chloride test: Test extract were treated with 4 drops of Alcoholic $\mathrm{FeCl}_{3}$ solution. Formation of bluish black colour indicate the presence of Phenol

\section{RESULTS AND DISCUSSION}

\section{Observations}

Table 1: Comparative Table of Phytoconstituents of Curcuma caesia

\begin{tabular}{|c|c|c|c|c|c|}
\hline Sl. No. & Phytochemicals & Petrolium Ether & Chloroform & Acetone & Methanol \\
\hline 1 & Alkaloids & $+\mathrm{ve}$ & $+\mathrm{ve}$ & $+\mathrm{ve}$ & $+\mathrm{ve}$ \\
\hline 2 & Terpinoid & $+\mathrm{ve}$ & $+\mathrm{ve}$ & $+\mathrm{ve}$ & $+\mathrm{ve}$ \\
\hline 3 & Phenols and Tannins & $+\mathrm{ve}$ & $+\mathrm{ve}$ & $+\mathrm{ve}$ & $+\mathrm{ve}$ \\
\hline 4 & Saponins & + ve & -ve & -ve & -ve \\
\hline 5 & Flavonoids & $+\mathrm{ve}$ & $+\mathrm{ve}$ & + ve & -ve \\
\hline 6 & Quinines & -ve & -ve & + ve & $+\mathrm{ve}$ \\
\hline 7 & Proteins & $+\mathrm{ve}$ & -ve & + ve & $+\mathrm{ve}$ \\
\hline 8 & Steroids & $+\mathrm{ve}$ & $+\mathrm{ve}$ & -ve & -ve \\
\hline 9 & Cardiac Glycosides & $+\mathrm{ve}$ & -ve & -ve & $+\mathrm{ve}$ \\
\hline 10 & Carbohydrates & -ve & -ve & $+\mathrm{ve}$ & $+\mathrm{ve}$ \\
\hline 11 & Amino Acid & -ve & $+\mathrm{ve}$ & -ve & -ve \\
\hline
\end{tabular}

\section{DISCUSSION}

This examination has found the nearness of empowering compound constituents. essential phytochemicals thought of as dynamic refreshing phytochemicals such terpenoids, diminishing sugar, flavonoids and alkaloids were blessing inside the examples. Various investigations have affirmed that saponins have the particular property of causative and coagulating red platelets and steroids and chargeable for cholesterol diminishing properties (Okwu, 2004) (Sodipo, 2000) Steroids moreover encourage in direction the insusceptible response (Shah, 2009) Alkaloids speak to a classification that influences the focal framework, lessens appetence and carries on as diuretic medicate.

The choice of rough plant removes for screening programs has the capability of being a great deal of palmy in beginning strides than the screening of unadulterated mixes separated from common stock. The plant extricate ar the supply of the optional metabolites i.e., alkaloids, flavonoids, terpenoids, tannins and so forth. The phytochemical examination of the liliopsid sort caesia is imperative and has in every business intrigue investigation establishments and prescription |prescribed drugs\} organizations for the creating of the new medications for treatment of arranged illnesses. liliopsid sort caesia has stimulating worth the nearness of those real constituents (Paliwal, 2012) (Saxena Jyoti and Sahu, 2012).

Present phytochemical ponder done by four natural solvents (Petrolium Ether, Acetone, Chloroform and Methanol). In methanolic rough concentrate sugars, proteins amino acids, glycosides, Flavonoids, Alkaloids, Tanins, phenols, saps are blessing. Steroids, saponins starch are missing (Reshma et. al., 2013) (Das et. al., 2013). (In methanolic unrefined concentrate demonstrates phenols are blessing in most astounding amount and flavonoids are blessing moderate while steroids and saponins are poor in methanolic) (Table 1).

\section{CONCLUSION}

The current study provides proof that solvent extract of Curcuma caesia contains medicinally necessary bioactive compounds and this justifies the employment of 
plant species as ancient medication for treatment of assorted diseases. More purification, identification and characterization of the bio active chemical constituent's compounds would be our priority in future studies.

Based on the result of this study it can be said that Curcuma caesia rhizomes and leaves is an effective antioxidant agent that can be used for folk medicine and will be a good source to treat and control many diseases. These findings could also be of commercial interest to both pharmaceutical companies and research institutes in the production of new drugs

\section{REFERENCES}

Arulmozhi D.K., Sridhar N., Veer-Anjaneyulu A. and Arora S.K., 2006. Preliminary mechanistic studies on the smooth muscle relaxant effect of hydro alcoholic extract of Curcuma caesia. J. Herb Pharmacotherapy, 6(3-4): 117-24.

Das S., Bordoloi P.K., Phukan D., Singh S., 2013. Study of the anti-ulcerogenic activity of the ethanolic extracts of rhizome of Curcuma caesia (eecc) against gastric ulcers in experimental animals, Asian J. Pharm. Clin. Res., 5: 200-203.

Kagyung, Gajurel P.R., Rethy P. and Singh B., 2010. Ethnomedicinal plant used for gastrointestinal diseases by Adi tribe of Dihang-Dibang biosphere reserve in Arunachal Pradesh., J. Trad. Know, 9: 496-501.

Okwu D.E., 2004. Phytochemicals and vitamin content of indigenous spices of southeastern Nigeria, J. Sustain Agric. Environ., 6: 30- 37.

Paliwal P., Pancholi S.S. and Patel R.K., 2011. Pharmacognostic parameters for evaluation of the rhizomes of Curcuma caesia, J. Adv. Pharm. Tech. Res., 2(1): 56-61.

Paliwal P., 2012. Pharmacognostic parameters for evaluation of the rhizomes of Curcuma caesia., J. Adv. Pharm. Tech. Res., 2: 56-61.

Pandey A.K. and Chowdhary A.R., 2003. Volatile constituents of rhizome oil of Curcuma caesia, Flavour Fragr J., 18(5): 463-465.
Rajamma A.G., Bai V. and Nambisan B., 2012. Antioxidant and antibacterial activities of oleoresins isolated from nine Curcuma species, Phytopharmacology, 2: $312-317$.

Rajesh H., Rao S.N., Megha Rani N., Prathima K., Rajesh E.P. and Chandrashekhar R., 2013. Phytochemical Analysis of Methanolic extract of Curcuma longa Linn., International Journal of Universal Pharmacy and Bio Sciences, 2(2): 39-45.

Reshma V., Lawand S. and Gandhi V., 2013. Comparison of Curcuma caesia Roxb. With other Commonly Used Curcuma Species by HPTLC, Journal of Pharmacognosy and Phytochemistry, 2(4): 126131.

Sarangthem K. and Haokip M.J., 2010. Bioactive components in Curcuma caesia Roxb. grown in Manipur, The Bioscan., 5: 113-115.

Sasikumar B., 2005. Genetic Resource of Curcuma: Diversity, Characterization and Utilization, Plant Genet Resource, 3(2): 230-251.

Saxena Jyoti J. and Sahu R., 2012. Evaluation of Phytochemical constituents in Conventional and Non-conventional species of Curcuma, International Research Journal of Pharmacy, 3(8): 203-204.

Shah B.A., 2009. Boswellic acids: a group of medicinally important compounds, Nat. Prod. Rep., 26: 72-89.

Sodipo O.A., 2000. Studies on certain characteristics of extracts of bark of Pansinystalia macruceras $(K$ schemp) pierre Exbeille., Global J. Pure Appl. Sci., 6: $83-87$.

Sonjit D., Prodyut M. and Kamaruz Z., 2013. Curcuma Caesia Roxb. and It's Medicinal Uses: A Review, Int. Journal of Research in Pharmacy and Chemistry, 3: 370-375.

Tag H., Das A.K. and Loyi H., 2007. Anti-inflammatory plant used by Khanti tribes of Lohit district in Arunachal Pradesh, Natural Product Radiate, 4: 340-343. 